Bull. Chem. Soc. Ethiop. 2013, 27(2), 179-189.

Printed in Ethiopia

ISSN 1011-3924

DOI: http://dx.doi.org/10.4314/bcse.v27i2.3

(c) 2013 Chemical Society of Ethiopia

\title{
FLUORIDE LEVELS IN COMMERCIALLY AVAILABLE RICE IN ETHIOPIA
}

\author{
Bisratewongel Tegegne, Bhagwan Singh Chandravanshi ${ }^{*}$ and Feleke Zewge \\ Department of Chemistry, Addis Ababa University, P.O. Box 1176, Addis Ababa, Ethiopia
}

(Received October 29, 2012; revised May 5, 2013)

\begin{abstract}
Rice (Oryza sativa, Asian; Oryza glaberrima, African) is an important staple food crop in many Sub-Saharan African and Asian countries, so the consumer's daily bowl of rice needs to be safe and of good quality. The objective of this study was to determine level of fluoride in raw and cooked rice by ion selective electrode. Alkaline fusion was used for sample preparation of six varieties for both the raw rice and rice cooked with tap water and fluoridated water. Fluoride levels ranged from $0.1-5.5 \mathrm{mg} / \mathrm{kg}$ in raw rice sample. Rice which was cooked with different fluoride levels of water showed increment depending on the method of cooking. In absorption method of cooking fluoride level was higher than that cooked by excess method and it may be due to the fact that all the fluoride in the water used for cooking by absorption method goes in to the grain while in excess method the remaining water was removed. The employed alkaline fusion procedure was evaluated using spiking method and an acceptable percentage recovery was obtained. A statistical analysis of variance at $95 \%$ confidence level for fluoride determination indicated significant difference between the mean of each variety of rice samples.
\end{abstract}

KEY WORDS: Fluoride, Ethiopian rice, Imported rice, Staple food, Cooking methods

\section{INTRODUCTION}

There are several studies reporting the dietary intake of fluoride from water, beverages and foods [1-8]. The main staple in Ethiopia is the enjera made from teff [9, 10]. Enjera is an unleavened bread prepared by fermentation of teff (Eragrostis tef (Zucc.)), wheat, barley, maize or sorghum, or from a mixture of these [11]. Teff seeds have high contents of calcium and iron, and are also rich in the sulfur containing amino acids cysteine and methionine [12]. Rice is becoming a new staple replacing traditional staple foods like teff, ensete kocho and bulla.

Rice is one of the commonly consumed cereals for more than half of the world's population. In many regions it is eaten with every meal and provides more calories than any other single food [13]. It is estimated that more than half of the population of India subsists on rice and it is among the important cereal crops grown in different part of Ethiopia as food crop [14]. Rice cultivation can now be found in all continents except Antarctica [15]. Because the rice plant is highly adaptable to local environment and because human has succeeded in modifying local agro-ecosystem, rice can now be grown in many different locations and under a variety of climates $[16,17]$.

In the history of rice breeding, a high-yielding rice variety called NERICA (New Rice for Africa) has been obtained for the first time from crosses between African rice (Oryza glaberrima) and Asian rice (Oryza sativa) at West African Rice Development Association (WARDA, Cotonou, Benin). This hybrid species replaced the low-yielding, lodging and shattering-prone Oryza glaberrima. It contains $2 \%$ more protein than their African or Asian parents. It is taller than most rice, making harvesting easier, pest resistant and tolerant to drought and infertile soils better than Asian varieties [18].

Rice is a cereal foodstuff which forms an important part of the diet of more than three billion people around the world [19]. Rice is also an important staple food crop in many SubSaharan African countries. Rice was introduced in Ethiopia during 1970s and has since been

*Corresponding author. E-mail: bscv2006@yahoo.com 
cultivated in small but increasing pockets of the country [20]. Its verities have different qualities that suit different food applications. The rice grain is mostly consumed boiled (or fried) as main staple but it is also widely used for snacks, appetizers, rice soups (congee) and desserts. It is also used as flour, for making rice wine, as ingredient for beer and liquor, and in the manufacture of cosmetics and textiles [21].

Unfortunately, rice is a poor source of many essential micronutrients and vitamins, and deficiencies in these micronutrients are common in developing countries [22]. Vitamin A, iron and iodine deficiency are the most wide spread and devastating forms of micronutrient malnutrition. The most widely consumed staple crops rice, wheat and maize are not good sources of these nutrients $[23,24]$. Teff is an excellent source of fiber and has many times the amount of calcium, potassium and other essential minerals found in an equal amount of other grains [25]. Red teff, the least expensive form and the least preferred type, has the highest iron content [26].

Different studies stated that most of the heavy metals were found to accumulate mainly in the roots of the rice plant, while other parts including the grains contained low levels [27, 28]. Varying levels of several metals such as $\mathrm{Na}, \mathrm{K}, \mathrm{Ca}, \mathrm{Mg}, \mathrm{Fe}, \mathrm{Mn}, \mathrm{Zn}, \mathrm{Ni}, \mathrm{Co}, \mathrm{Cd}$, and $\mathrm{Pb}[21,28-$ 33 ] in different types of rice of different origin have been reported in the literature.

Fluoride is a necessary element to human health, and a moderate amount of fluoride intake is confirmed that it is the effective way of reducing dental caries among children and adult. However, excessive fluoride intake through drinking water or food results in dental fluorosis and skeletal fluorosis [34, 35].

Drinking water is traditionally considered to be the main source of fluoride and, therefore, artificial fluoridation is common in many water supplies [36]. Daily intakes of fluoride vary widely according to the various sources of exposure. Virtually all foodstuffs contain at least traces of fluorine. All vegetation contains some fluoride, which is absorbed from soil and water [35]. Intake of fluoride is variable and is derived from a number of sources in the diet and the environment [37]. In the Ethiopian Rift Valley surface water has natural high fluoride content [38], and both cereals [1] and food may contribute significantly to the daily fluoride intake [5, 7].

Unlike other cereals, rice is consumed largely as cooked whole kernels, which is produced after de-hulling and milling processes. Optimum cooking degree of rice is usually determined when rice reaches an end cooking point where it either absorb a maximum amount of water or until the core of the cooked rice kernels gelatinize [39]. Although cooking methods for rice vary widely worldwide, rice-cooking methods are mostly subtle variations of two basic cooking techniques: namely, excess or American method, where rice is usually cooked in a large amount of water then drained which is $1: 15 \mathrm{w} / \mathrm{v}$ and, absorption or oriental method, where rinsed rice is usually cooked in a measured amount of water which is 1:5 w/v, [40]. Rice-kernel surface area and chemical composition also affect cooked-rice moisture uptake during cooking [41, 42].

There are no reports in the literature about the levels of fluoride in commercially available imported and Ethiopian rice. Thus the objectives of the present study were to: (i) determine the levels of fluoride in six varieties of raw rice and rice cooked in tap water and fluoridated water by the absorption and excess methods of cooking, (ii) assess the cooking effect in fluoride level, and (iii) compare the levels of fluoride in commercially available imported and Ethiopian rice with data obtained from other countries. The results of this study may provide useful baseline data on the levels of fluoride in selected rice samples. 


\section{EXPERIMENTAL}

\section{Instrumentation}

Orion $\mathrm{F}$ ion selective electrode was used for the determination of $\mathrm{F}$ ion in water samples, raw and cooked rice samples. A pH/ISE meter (Orion Model, EA 940 Expandable Ion Analyzer) equipped with combination fluoride-selective electrode (Orion Model 96-09) was employed. The $\mathrm{pH}$ was measured with $\mathrm{pH} /$ ion meter (WTW Inolab pH/ION Level 2, Germany) using unfilled $\mathrm{pH}$ glass electrode. All potential and $\mathrm{pH}$ measurements were made at room temperature $\left(22 \pm 2{ }^{\circ} \mathrm{C}\right)$.

\section{Chemicals and reagents}

All the reagents used were of analytical grade. Sodium fluoride $(99.0 \% \mathrm{NaF}$, BDH Chemicals England) was used to prepare fluoride stock standard solution. Glacial acetic acid (99.5\%, BDH chemicals, England), sodium chloride (Scharlau, European Union), sodium citrate (ResearchLab Fine Chem. Industries Mumbai 400 002, India) and EDTA (Reagent grade, Spain) to prepare total ionic strength adjustment buffer (TISAB) solution, sodium hydroxide (Scharlau, European Union) solution to adjust $\mathrm{pH}$ of TISAB solution and hydrochloric acid (Scharlau, European Union) to adjust $\mathrm{pH}$ of the sample solutions.

\section{Sampling}

Sample areas were selected according to the areas in which rice is available to the users. A total of eighteen rice samples (three samples for each of six varieties of rice sample) were collected. Basmati (BR), Jasmine (JR), Royal (RR) and Ethiopian white rice (EWR) were collected from three randomly selected supermarkets in which all the four varieties of rice was available that was found in Addis Ababa to ensure that each particular variety of the rice sample was collected from three different supermarkets. For Ethiopian red rice (ERR) Fogera was selected to collect the sample because it is the main rice production area next to Metema found in Ethiopia. The sample was not collected from Metema because of time availability that the place is very far from the research place. The last sample NERICA (New Rice for Africa) was collected from Amhara Regional Agricultural Research Institute (ARARI) Bahir Dar, Ethiopia. ARARI was selected because this rice variety is present in this institute in pure form but in other place exist with adulterant. This variety of sample was collected from three selected sub-sample sites. $1 \mathrm{~kg}$ of each of the six varieties of rice sample was collected from three sub-sample sites and mixed to form $3 \mathrm{~kg}$ bulk sample of each of the six varieties. Tap water was collected from Addis Ababa potable water pipe in clean plastic polyethylene container (Jerican) and used for preparation of $3 \mathrm{mg} / \mathrm{L}, 6 \mathrm{mg} / \mathrm{L}$ and $10 \mathrm{mg} / \mathrm{L}$ fluoridated water for cooking the rice in the laboratory.

\section{Pre-treatment of raw rice}

All the raw rice samples were washed with tap water followed by deionised water to avoid any dust materials on the grain, and dried until constant weight. The dried rice sample was then ground using a blender device in the laboratory and sieved through a $0.457 \mathrm{~mm}$ sieve to remove large grains. 


\section{Preparation of cooked rice}

Rice was cooked in two different methods of cooking, namely absorption and excess method [39]. About $135 \mathrm{~g}$ of each rice sample were cooked in tap water in which the level of fluoride was $0.2 \mathrm{mg} / \mathrm{L}$, and in tap water added fluoride to the levels of 3, 6 and $10 \mathrm{mg} \mathrm{F} / \mathrm{L}$. Difference in amount of water used and time taken to finish cooking were observed by keeping the temperature constant. The amount of water added and the time needed for cooking the rice samples are given in Table 1 .

Table 1. Amount of water added and time needed for cooking the rice samples.

\begin{tabular}{|l|c|c|c|}
\hline \multirow{2}{*}{ Type of rice samples } & \multicolumn{2}{|c|}{ Cooking method and amount of water in mL } & Cooking time \\
\cline { 2 - 3 } & Absorption method & Excess method & (min) \\
\hline Basmati rice (BR) & 380 & 760 & 35 \\
\hline Jasmine rice (JR) & 340 & 700 & 30 \\
\hline Royal rice (RR) & 500 & 825 & 50 \\
\hline Ethiopian white rice (EWR) & 300 & 615 & 25 \\
\hline Ethiopian red rice (ERR) & 340 & 700 & 30 \\
\hline New Rice for Africa (NERICA) & 460 & 790 & 45 \\
\hline
\end{tabular}

After the cooking process was completed, the cooked rice was allowed to dry to constant weight. The cooked and dried rice was then ground and sieved by $0.457 \mathrm{~mm}$ sieve and kept in a plastic bag at the laboratory pending fluoride determination.

\section{Samples preparation for fluoride determination}

In the raw and cooked rice total fluoride was determined using the alkaline fusion method [5, 43].

\section{Method validation for fluoride determination}

In the absence of certified reference material, the validity of the procedure was checked by carrying out with a lower level of traceability, such as spiked samples. The spiked samples were prepared by adding a known quantity of fluoride standard solution to the rice sample by applying similar procedure to prepare the sample and analyzed for the levels of fluoride to calculate the recovery percent. Rice samples were spiked with fluoride solution in which the fluoride content was equivalent to $25 \%, 50 \%$, or $100 \%$ of the fluoride content of the original (unspiked) rice samples.

The generally accepted and common definition of method detection limit is the concentration that gives a signal three times the standard deviation of the blank or background signal $[44,45]$. In this study, it was calculated as three times the standard deviation of the blank ( $3 \sigma_{\text {blank }}$, where $\sigma=$ standard deviation of the blanks). The lowest concentration level at which a measurement is quantitatively meaningful is called the limit of quantification (LOQ). The LOQ is most often defined as 10 times the signal/noise ratio. If the noise is approximated as the standard deviation of the blank $\left(\mathrm{S}_{\mathrm{b}}\right)$, the LOQ is $10 \times \mathrm{S}_{\mathrm{b}}$ [46]. The detection limit of the fluoride ion selective electrode potentiometry used was $0.02 \mathrm{mg} \mathrm{F} / \mathrm{L}$ and limit of quantification for the rice sample was found to be $0.03 \mathrm{mg} \mathrm{F} / \mathrm{kg}$. 


\section{RESULTS AND DISCUSSION}

\section{Recovery results of fluoride determination}

Recovery results of fluoride determination in rice sample are presented in Table 2. As shown in Table 2, the percentage recoveries of the measured sample were found within the acceptable range $(92-105 \%)$.

Table 2. Recovery results of fluoride determination in rice samples.

\begin{tabular}{|c|c|c|c|c|}
\hline \multirow[t]{2}{*}{ Sample type } & \multicolumn{3}{|c|}{ Concentration $(\mathrm{mg} / \mathrm{kg})$} & \multirow{2}{*}{$\begin{array}{c}\text { Recovery } \\
(\%)\end{array}$} \\
\hline & in unspiked sample & added & in spiked sample & \\
\hline \multirow[t]{3}{*}{ Jasmine rice (raw) } & $2.1 \pm 0.1$ & 0.5 & $2.5 \pm 1.5$ & $92 \pm 2$ \\
\hline & $2.1 \pm 0.1$ & 1.1 & $3.1 \pm 0.4$ & $97 \pm 2$ \\
\hline & $2.1 \pm 0.1$ & 2.1 & $4.1 \pm 0.8$ & $95 \pm 4$ \\
\hline \multirow{3}{*}{$\begin{array}{l}\text { Ethiopian white rice } \\
\text { cooked } \\
\text { (tap water absorption) }\end{array}$} & $1.4 \pm 0.5$ & 0.4 & $1.9 \pm 0.6$ & $105 \pm 1$ \\
\hline & $1.4 \pm 0.5$ & 0.7 & $2.1 \pm 1.2$ & $97 \pm 2$ \\
\hline & $1.4 \pm 0.5$ & 1.4 & $2.7 \pm 1.7$ & $92 \pm 2$ \\
\hline \multirow{3}{*}{$\begin{array}{l}\text { Basmati rice cooked } \\
\text { (tap water excess ) }\end{array}$} & $6.0 \pm 0.2$ & 1.5 & $7.6 \pm 0.1$ & $102 \pm 5$ \\
\hline & $6.0 \pm 0.2$ & 3.0 & $9 \pm 0.8$ & $99 \pm 7$ \\
\hline & $6.0 \pm 0.2$ & 6.0 & $11.9 \pm 4.2$ & $97 \pm 1$ \\
\hline
\end{tabular}

Levels of fluoride in rice sample

Level of fluoride in raw rice. The levels of fluoride in raw rice were found to be Basmati $5.2 \pm 0.07 \mathrm{mg} \mathrm{F} / \mathrm{kg}$, Jasmine $2.2 \pm 0.08 \mathrm{mg} \mathrm{F} / \mathrm{kg}$, Royal rice $0.43 \pm 0.01 \mathrm{mg} \mathrm{F} / \mathrm{kg}$, Ethiopian white rice $0.1 \pm 0.01 \mathrm{mg} \mathrm{F} / \mathrm{kg}$, Ethiopian red rice $4.4 \pm 0.1 \mathrm{mg} \mathrm{F} / \mathrm{kg}$, and NERICA $2.5 \pm 0.09 \mathrm{mg} \mathrm{F} / \mathrm{kg}$. Level of fluoride varied depending on the type of rice. The difference might be due to difference in their genetic makeup, the variety of rice plant, fertilizer used, soil type, and quality of water used for plantation [32]. The level of fluoride in the rice samples ranged from 0.1-5.2 mg F/ $\mathrm{kg}$. The fluoride levels in wheat, maize and red teff flour have been reported to be 6.82, 12.2 and $15.1 \mathrm{mg} \mathrm{F} / \mathrm{kg}$, respectively [47]. Thus relative to the reported values in other staple foods in Ethiopia, fluoride levels in rice sample are lower. Basmati rice contained the highest level of 5.2 $\mathrm{mg} \mathrm{F} / \mathrm{kg}$ and Ethiopian white rice contained the lowest level of $0.1 \mathrm{mg} \mathrm{F} / \mathrm{kg}$. The level of fluoride in rice samples showed the trend $\mathrm{BR}>\mathrm{ERR}>\mathrm{NERICA}>\mathrm{JR}>\mathrm{RR}>\mathrm{EWR}$. Amount of fluoride present in the rice grain might be affected by the amount present in the soil, the acidity of the soil and the capability of the plant to absorb fluoride from the soil or from the water since rice needs larger amount of water to grow than other plants.

Level of fluoride in cooked rice. Rice sample collected from different sample sites were cooked in water with different levels of fluoride water by absorption and excess cooking methods. Fluoridated water with 3,6 and $10 \mathrm{mg} \mathrm{F} / \mathrm{L}$ and tap water with $0.2 \mathrm{mg}$ F/L were used for cooking. The results are presented in Tables 3, 4 and 5.

As shown in Table 3 and 4 the calculated amount of fluoride by assuming that all the fluoride present in the water totally goes into the rice grain, is comparable with fluoride present in cooked rice. This might be due to the adsorption of fluoride into the cooked rice and/or the binding of fluoride by the cations present in the cooked rice which prevent the loss of fluoride by evaporation during the cooking. The difference is not as such significant and it is possible to conclude that in absorption method of cooking almost all fluoride present in the water goes in to the grain. 
Table 3. Average level of fluoride in cooked rice by absorption method (mean $\pm \mathrm{SD}, \mathrm{n}=9, \mathrm{mg} / \mathrm{kg}$ dry weight).

\begin{tabular}{|l|c|c|c|c|}
\hline \multirow{2}{*}{$\begin{array}{l}\text { Type of } \\
\text { rice }\end{array}$} & \multicolumn{4}{|c|}{ Mean \pm SD of fluoride in rice cooked by absorption method $(\mathrm{mg} / \mathrm{kg})$} \\
\cline { 2 - 5 } & $\begin{array}{c}\text { Cooked in tap water } \\
\text { with fluoride }(0.2 \mathrm{mg} / \mathrm{L})\end{array}$ & Calculated $(\mathrm{mg} / \mathrm{kg})$ & $\begin{array}{c}\text { Cooked in water with } \\
\text { fluoride }(3 \mathrm{mg} / \mathrm{L})\end{array}$ & $\begin{array}{c}\text { Calculated } \\
(\mathrm{mg} / \mathrm{kg})\end{array}$ \\
\hline BR & $5.5 \pm 0.4$ & 5.9 & $13.9 \pm 0.9$ & 13.8 \\
\hline JR & $2.4 \pm 0.1$ & 2.7 & $8.9 \pm 0.1$ & 9.8 \\
\hline RR & $0.9 \pm 0.06$ & 1.2 & $11.5 \pm 0.8$ & 11.5 \\
\hline EWR & $0.4 \pm 0.03$ & 0.6 & $5.8 \pm 0.1$ & 6.8 \\
\hline ERR & $4.8 \pm 0.3$ & 5.1 & $13.8 \pm 1.2$ & 14.6 \\
\hline NERICA & $2.8 \pm 0.2$ & 3.2 & $11.4 \pm 0.8$ & 12.7 \\
\hline
\end{tabular}

Table 4. Average level of fluoride in cooked rice by absorption method (mean $\pm \mathrm{SD}, \mathrm{n}=9, \mathrm{mg} / \mathrm{kg}$ dry weight).

\begin{tabular}{|l|c|c|c|c|}
\hline \multirow{2}{*}{$\begin{array}{l}\text { Types of } \\
\text { rice }\end{array}$} & \multicolumn{4}{|c|}{ Mean \pm SD of fluoride in rice cooked by absorption method } \\
\cline { 2 - 5 } & $\begin{array}{c}\text { Cooked in water with } \\
\text { fluoride }(6 \mathrm{mg} / \mathrm{L})\end{array}$ & $\begin{array}{c}\text { Calculated } \\
(\mathrm{mg} / \mathrm{kg})\end{array}$ & $\begin{array}{c}\text { Cooked in water with } \\
\text { fluoride }(10 \mathrm{mg} / \mathrm{L})\end{array}$ & $\begin{array}{c}\text { Calculated } \\
(\mathrm{mg} / \mathrm{kg})\end{array}$ \\
\hline BR & $20.5 \pm 1.2$ & 22.3 & $30.8 \pm 2.4$ & 33.5 \\
\hline JR & $16.2 \pm 0.8$ & 17.3 & $26.2 \pm 1.1$ & 27.4 \\
\hline RR & $20.4 \pm 0.6$ & 22.7 & $35.5 \pm 1.5$ & 37.5 \\
\hline EWR & $12.4 \pm 0.9$ & 13.5 & $20.7 \pm 1.6$ & 22.3 \\
\hline ERR & $22.5 \pm 1.7$ & 24.8 & $36.2 \pm 3.5$ & 38.5 \\
\hline NERICA & $16.7 \pm 0.4$ & 17.6 & $26.5 \pm 0.6$ & 27.7 \\
\hline
\end{tabular}

Table 5. Average level of fluoride in cooked rice by excess method (mean $\pm \mathrm{SD}, \mathrm{n}=9, \mathrm{mg} / \mathrm{kg}$ dry weight).

\begin{tabular}{|l|c|c|c|c|}
\hline \multirow{2}{*}{$\begin{array}{l}\text { Type of } \\
\text { rice }\end{array}$} & \multicolumn{4}{|c|}{ Mean \pm SD of fluoride in rice cooked by excess method (mg/kg) } \\
\cline { 2 - 5 } & $\begin{array}{c}\text { Cooked in tap water with } \\
\text { fluoride }(0.2 \mathrm{mg} / \mathrm{L})\end{array}$ & $\begin{array}{c}\text { Cooked in water with } \\
\text { fluoride }(3 \mathrm{mg} / \mathrm{L})\end{array}$ & $\begin{array}{c}\text { Cooked in water with } \\
\text { fluoride }(6 \mathrm{mg} / \mathrm{L})\end{array}$ & $\begin{array}{c}\text { Cooked in water with } \\
\text { fluoride }(10 \mathrm{mg} / \mathrm{L})\end{array}$ \\
\hline BR & $3.2 \pm 0.24$ & $6.6 \pm 0.5$ & $14.5 \pm 1.2$ & $18.6 \pm 0.5$ \\
\hline JR & $2.3 \pm 0.1$ & $4.9 \pm 0.4$ & $8.2 \pm 0.7$ & $12.6 \pm 1.1$ \\
\hline RR & $0.5 \pm 0.04$ & $5.8 \pm 0.5$ & $12.7 \pm 0.3$ & $17.3 \pm 1.1$ \\
\hline EWR & $0.2 \pm 0.01$ & $3.5 \pm 0.1$ & $7.2 \pm 0.4$ & $10.8 \pm 0.8$ \\
\hline ERR & $4.5 \pm 0.2$ & $9.9 \pm 0.4$ & $15.2 \pm 1.8$ & $19.8 \pm 1.3$ \\
\hline NERICA & $2.6 \pm 0.3$ & $7.4 \pm 0.5$ & $10.1 \pm 0.6$ & $15.9 \pm 1.4$ \\
\hline
\end{tabular}

BR: Basmati rice, JR: Jasmine rice, RR: Royal rice, EWR: Ethiopia rice, ERR: Ethiopia red rice, NERICA: New rice for Africa.

The comparison of levels of fluoride in the rice cooked by absorption method is presented in Figure 1. As shown in Figure 1 the trend is different from the order in raw rice. The reason for this difference might be due to the fact that each sample requires different volume of water and time for cooking. The amount of water used, time needed for cooking and the nature of the variety of the rice determine the fluoride level in the cooked rice sample. It also might be due to difference in variety and species (Ethiopian rice belongs to Oyiza glaberrima and imported one to Oryza sativa).

The comparison of fluoride levels in rice cooked by excess method is shown in Figure 2. The trend is different from the order in raw rice and as well as in the rice cooked by absorption method. The amount of water and time used for cooking and the nature and the variety of rice determine the fluoride level in the cooked rice sample. The results showed that the level of fluoride in the rice cooked by the excess method is lower than the absorption method. The reason for this might be due to the fact that fluoride in excess method of cooking goes with the 
water which was discarded or removed. In Ethiopia, the most common method of cooking rice is absorption. Therefore, in the areas in which fluoride is highly accumulated in the water that are used for cooking rice selecting excess method of cooking is advisable.

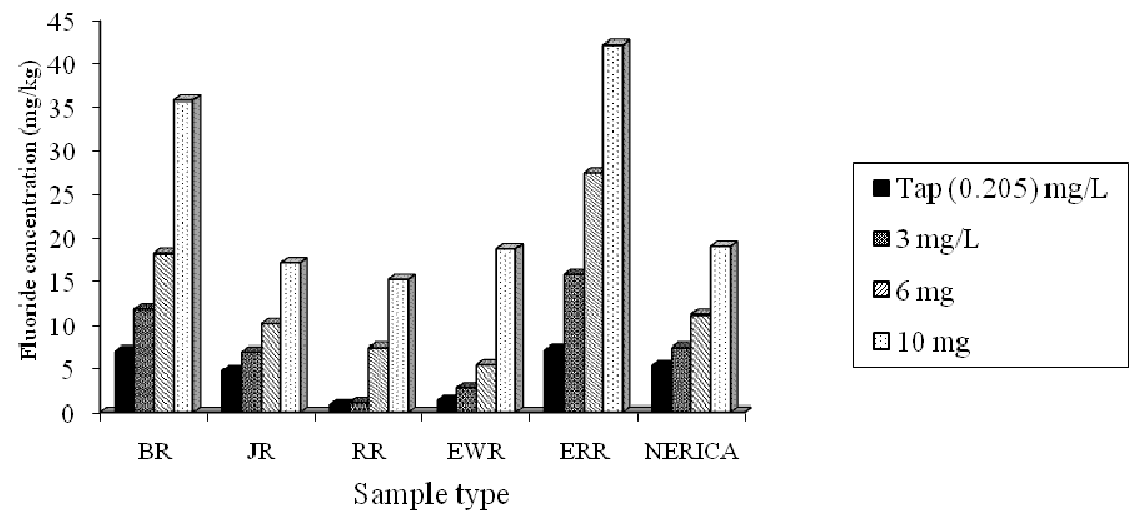

Figure 1. Levels of fluoride in cooked rice by absorption method.

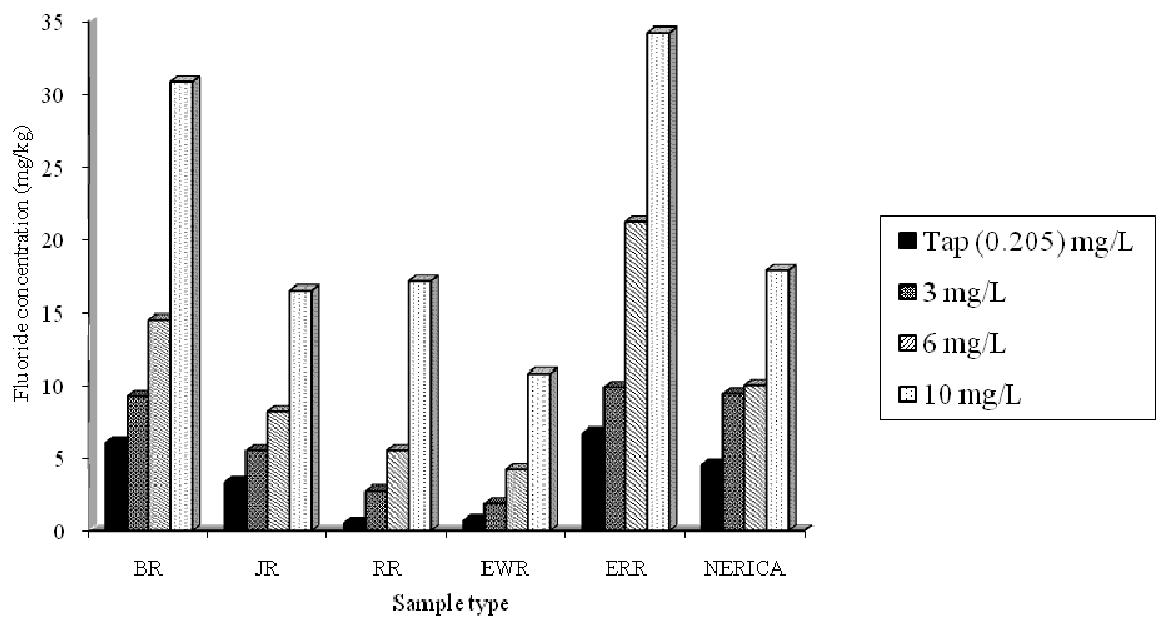

Figure 2. Levels of fluoride in cooked rice by excess method.

From the results in Tables 3, 4 and 5, absorption method provides in large extent to the level of fluoride present in the cooked rice than excess method and should be avoided. Among the six rice samples, the rice imported from abroad (Royal rice) is preferable due to the lowest fluoride levels. Among the three local rice samples, Ethiopian white rice is preferable over other Ethiopian rice and excess method of cooking rice is most advisable to cook rice. It is advisable to select a variety of rice with low fluoride content especially for peoples who live around Rift Valley Region where fluoride level of the water is higher. 
Comparison of fluoride levels in this study with literature values

The comparative studies of fluoride level in rice sample determined in this study and other staple food items reported in literature have been made. The fluoride level in this study has wide variation between sample varieties (0.1-6.4 mg/kg) relative to the reported values. Except Sona rice variety $(10.3 \mathrm{mg} / \mathrm{kg}$ ) from Hyderabad (India) [14], other variety from other country, Hansa rice from Hyderabad (India) [14], C rice from Brazil [32] have comparable value of fluoride $(0.1-0.5 \mathrm{mg} / \mathrm{kg})$ with this study. Fluoride level reported in Brazil for rice variety A and B show smaller values $(0.02 \mathrm{mg} / \mathrm{kg})$ [32] than the value reported in this study. Similarly fluoride levels in cooked rice in Iran ranged from 0.2-1.6 mg F/ $\mathrm{kg}$ [2]. Reported fluoride level in rice is ranged from $0.02-10.3 \mathrm{mg} \mathrm{F} / \mathrm{kg}$ and the reported values of fluoride in other staple food (wheat flour $6.82 \mathrm{mg} \mathrm{F} / \mathrm{kg}$, maize flour $12.2 \mathrm{mg} \mathrm{F} / \mathrm{kg}$, red teff flour $15.1 \mathrm{mg} \mathrm{F} / \mathrm{kg}$ ) items ranged from 6.82$15.1 \mathrm{mg} \mathrm{F} / \mathrm{kg}$ [47]. While in another study the fluoride levels reported are wheat flour $5.6 \mathrm{mg}$ $\mathrm{F} / \mathrm{kg}$, red teff flour $6.9 \mathrm{mg} / \mathrm{kg}$, white teff flour $6.7 \mathrm{mg} \mathrm{F} / \mathrm{kg}$, maize flour $1.2 \mathrm{mg} \mathrm{F} / \mathrm{kg}$, ensete kocho $1.0 \mathrm{mg} \mathrm{F} / \mathrm{kg}$, and ensete bulla $1.9 \mathrm{mg} / \mathrm{F} / \mathrm{kg}$ [1]. Thus the levels of fluoride found in this study are in between the reported levels of fluoride in rice and other staple food items. This might be due to the amount of fluoride in the soil is moderately fluoridated where the reported food item is grown.

Analysis of variance

Variation in the mean levels of fluoride between the samples were tested whether it was from a random error or treatment (difference in mineral contents of soil, water, atmosphere; variation in application of agrochemicals like fertilizers, pesticides, herbicides, or other variations in cultivation procedures) [48]. The results showed that for fluoride, at the $95 \%$ confident level, the means were significantly different $(\mathrm{p}<0.05)$.

\section{Fluoride intake from rice}

The fluoride level of Basmati rice from the imported category and Ethiopian white rice from the local category both respectively cooked with tap and fluoridated water using absorption method of cooking which is commonly practiced in Ethiopia ranged from 5.5-30.8 mg/kg and $0.4-20.7 \mathrm{mg} / \mathrm{kg}$ from water fluoride ranged $0.2-10 \mathrm{mg} / \mathrm{L}$, respectively. By assuming that an average adult person consumes 100-200 g of rice every day, the daily fluoride intake only from rice without considering other source of fluoride ranged from 0.05-6.2 mg in Basmati rice and from $0.04-7.1 \mathrm{mg}$ in which the fluoride level in cooking water ranged from $0.2-10 \mathrm{mg} / \mathrm{L}$. The fluoride levels in both the rice cooked in water with fluoride level $0.2-6 \mathrm{mg} / \mathrm{L}$ are within the range of recommended level of fluoride for an adult person that is $4 \mathrm{mg} \mathrm{F} / \mathrm{kg}$ [49]. However consuming $200 \mathrm{~g}$ rice cooked by $10 \mathrm{mg} / \mathrm{L}$ fluoride level of water it exceeds the recommended daily intake and hence the person should change their diet to other staple foods which require less consumption of water during its preparation and cooking. On the other hand for children and teenagers daily intake of fluoride from rice cooked by water with fluoride level ranged 0.2-6 $\mathrm{mg} / \mathrm{L}$ are safe to consume based on the daily consumption of $100 \mathrm{~g}$ of rice alone [49]. But cooking with $10 \mathrm{mg} / \mathrm{L}$ of water exceeds the recommended range and therefore, children and teenagers living in the area where water fluoride levels are high should change their diet from rice to other stable foods which require less consumption of water during its preparation and cooking. In daily consumption of $200 \mathrm{~g}$ rice cooked with fluoride level of 0.2 and $3 \mathrm{mg} / \mathrm{L}$ is safe to consume it alone but cooked with 6 and $10 \mathrm{mg} / \mathrm{L}$ fluoride water exceeds the recommended range and therefore, people living in the area (rift valley region) where water fluoride levels are 
high should reduce their rice consumption and change their diet to other stable foods. The results are shown in Table 6.

Table 6. Expected daily fluoride intake from Basmati and Ethiopian white rice cooked in water with different fluoride levels by absorption method (consuming 100 and $200 \mathrm{~g}$ of rice every day in $\mathrm{mg}$ ).

\begin{tabular}{|l|c|c|c|c|c|c|c|c|}
\hline Type of rice & \multicolumn{2}{|c|}{ Tap $(0.2) \mathrm{mg} / \mathrm{L}$} & \multicolumn{2}{c|}{$3 \mathrm{mg} / \mathrm{L}$} & \multicolumn{2}{c|}{$6 \mathrm{mg} / \mathrm{L}$} & \multicolumn{2}{c|}{$10 \mathrm{mg} / \mathrm{L}$} \\
\cline { 2 - 9 } & $\begin{array}{l}100 \mathrm{~g} \text { rice } \\
\text { every day }\end{array}$ & $\begin{array}{l}200 \mathrm{~g} \text { rice } \\
\text { every day }\end{array}$ & $\begin{array}{l}100 \mathrm{~g} \text { rice } \\
\text { every day }\end{array}$ & $\begin{array}{l}200 \mathrm{~g} \text { rice } \\
\text { every day }\end{array}$ & $\begin{array}{l}100 \mathrm{~g} \text { rice } \\
\text { every day }\end{array}$ & $\begin{array}{l}200 \mathrm{~g} \text { rice } \\
\text { every day }\end{array}$ & $\begin{array}{l}100 \mathrm{~g} \text { rice } \\
\text { every day }\end{array}$ & $\begin{array}{c}200 \mathrm{~g} \text { rice } \\
\text { every day }\end{array}$ \\
\hline Basmati rice & 0.6 & 1.1 & 1.2 & 2.4 & 2.1 & 4.1 & 3.1 & 6.2 \\
\hline $\begin{array}{l}\text { Ethiopian } \\
\text { white rice }\end{array}$ & 0.04 & 0.1 & 0.6 & 1.2 & 2.04 & 4.1 & 3.6 & 7.1 \\
\hline
\end{tabular}

\section{CONCLUSION}

Commercially available rice varieties were collected from different sampling sites for fluoride analysis. The order of fluoride level obtained was Basmati rice $>$ Ethiopian red rice $>$ New Rice for Africa $>$ Jasmine rice $>$ Royal rice $>$ Ethiopian white rice. The study showed that rice could absorb fluoride from water while cooking and as fluoride level increases in the water used for cooking, fluoride absorbed by rice also increases. Analysis of variance showed that there was significant difference at $95 \%$ confidence level in the mean fluoride level in the samples. The amount of fluoride in the water used to cook the rice has effect on the recommended daily intake of fluoride.

\section{ACKNOWLEDGEMENTS}

The authors express their gratitude to the Department of Chemistry, Addis Ababa University, Ethiopia, for providing the laboratory facilities. Bisratewongel Tegegne is thankful to the Ministry of Education, Ethiopia, for sponsoring her study.

\section{REFERENCES}

1. Malde, M.K.; Måge, A.; Julshamn, K.; Macha, E.; Bjorvatn, K. J. Food Comp. Anal. 1997, $10,233$.

2. Zohouri, F.V.; Rugg-Gunn, A.J. Int. J. Food Sci. Nutr. 1999, 50, 265.

3. Zohouri, F.V.; Rugg-Gunn, A.J. Int. J. Food Sci. Nutr. 2000, 51, 317.

4. Zohouri, F.V.; Rugg-Gunn, A.J. Br. J. Nutr. 2000, 83, 15.

5. Malde, M.K.; Zerihun, L.; Julshamn, K.; Bjorvatn, K. Int. J. Paediatr. Dent. 2004, 14, 167.

6. Malde, M.K.; Greiner-Simonsen, R.; Julshamn, K.; Bjorvatn, K. Sci. Total Environ. 2006, $366,915$.

7. Malde, M.K.; Scheidegger, R.; Julshamn, K.; Bader, H.-P. Environ. Health Persp. 2011, 119, 579.

8. Battaleb-Looie, S.; Moore, F.; Malde, M.K.; Jacks, G. J. Food Comp. Anal. 2013, 29, 94.

9. Ketema, S. Teff. [Eragrostis teff (Zucc.) Trotter]: Promoting the Conservation and use of Underutilized and Neglected Crops, Institute of Plant Genetics and Crop Plant Research, International Plant Genetic Resources Institute (IPGRI), Biodiversity Institute, Addis Ababa, 1997.

10. Bultosa, G. J. Appl. Sci. 2007, 3, 2042.

11. Stewart, R.B.; Getachew, A. Econ. Bot. 1962, 16, 127. 
12. Ågren, G.; Eklund, A.; Liedén, S.Å. Food Composition Table for use in Ethiopia II. Amino Acid Content and Biological Data on Proteins in Ethiopian Foods. Swedish International Development Authority and Ethiopian Nutrition Institute: Stockholm and Addis Ababa; 1975; pp 1-33.

13. Pishgar, H.S.; Sefeedpari, P.; Rafiee, S. Energy 2011, 36, 5824.

14. Anasuya, A.; Paranjape, P. Fluoride 1996, 29, 193.

15. Yadav, B.K.; Jindal, V.K. J. Food Eng. 2007, 80, 46.

16. Takele, A. Analysis of Rice Profitability and Marketing Chain: The Case of Fogera Woreda, South Gonder Zone, Amahara Regional State, Ethiopia, M.Sc. Thesis, Department of Agricultural Economics, Haramaya University, Ethiopia, 2010.

17. Mandal, K.G.; Misra, A.K.; Hati, K.M. Food Agric. Environ. 2004, 2, 224.

18. Sarla, N.; Swamy, P.B. Curr. Sci. 2005, 89, 955.

19. Skaria, R.; Muneer, P. Genet. Eng. Biotechnol. J. 2011, $24,1$.

20. Gebremeskel, B.K. Rice Value Chain in Metema District, North Gonder Ethiopia, Challenges and Opportunities for Innovation, M.Sc Thesis, Institute of Regional and Local Development Studies, College of Development Studies, Addis Ababa University, Ethiopia, 2010.

21. Julie, Z. The Toxicity Assessment of Heavy Metal and Their Species in Rice, M.Sc. Thesis, Department of Chemistry, University of Cincinnati, USA, 2009.

22. Narayanan, N.N.; Vasconcelos, W.M.; Grusak, A.M. Plant Physiol. Biochem. 2007, 45, 277.

23. Kennedy, G.; Burlingame, B. Food Chem. 2003, 80, 589.

24. Chanakan, P.; Glahn, P.R.; Cheng, Z.; Fukai, S. Rerkasem, B.; Huang, L. Food Chem. 2009, $111,982$.

25. Jansen, G.R.; DiMaio, L.R.; Hause, N.L. J. Agric. Food Chem. 1962, $10,62$.

26. Deckers, J.; Nachtergaele, F.; Spaargaren, O. World Reference Base for Soil Resource: Belgium; Agricultural Cooperative Council of Oregon, Leuven/Amersfoort, 1998.

27. Kingsawa, R.; Roachanakanan, R. J. Environ. Nat. Resour. 2011, 9, 38.

28. Adezrian, D.J.; Khairiah, J.; Ismai, S.B.; Mahir, R.A. J. Agric. Environ. Sci. 2009, 6, 16.

29. Lin, T.H.; Wong, S.S.; Li, C.G. J. Food Drug Anal. 2004, 12, 167.

30. Zhou, Q.; Liu, J.; Liu, W.; Wang, T.; Zhng, Q.; Jiang, G. J. Chemosphere 2008, 71, 1269.

31. Fregal, G.C. Mol. Aspect. Med. 2005, 26, 235.

32. Renato, C.; Casarin,V.; Daniel, R.; Fernandes, M. Rev Saúde Pública 2007, 41, 1.

33. Mehdi, M.S.; Abbas, G.; Hassan, G. Pak. J. Appl. Sci. 2003, 3, 462-473.

34. Liub, Q.; Wanga, W.; Lin-sheng Yanga, L.; Fenga, F.; Zhaoa, X. J. Hazard. Mater. 2009, $167,892$.

35. World Health Organization Fluoride in Drinking Water, World Health Organization, Geneva, 2004.

36. Chandrajith, R.; Abeypala, U.; Dissanayake, B.C. J. Environ. Health 2007, 29, 429.

37. Simposom, A.; Shaw, L.; Smith, A.J. J. Dent. 2001, 29, 15.

38. Reimann, C.; Bjorvatn, K.; Frengstad, B.; Melaku, Z.; Tekle-Haimanot, R.; Siewers, U. Sci. Total Environ. 2003, 311, 65.

39. Buzalaf, M.L.; Leite, A.L.; Carvalho, N.T. J. Fluorine Chem. 2008, 129, 691.

40. Saleh, M.; Meullene, F.J. Rice Quality and Processing 2007, 251.

41. Bello, M.; Baeza, R.; Tolaba, P.M. J. Food Eng. 2006, 72, 124.

42. Cihan, A.; Kahveci, K.; Hacıhafızog, O. J. Food Eng. 2007, 79, 293.

43. Malde, M.K.; Bjorvatn, K.; Julshamn, K. Food Chem. 2001, 73, 373.

44. Settle, F. Handbook of Instrumental Techniques for Analytical Chemistry, Prentice Hall: New Jersey; 1997; pp 73-78. 
45. Huber, L. Validation and Qualification in Analytical Laboratories, 2nd ed., Informa Healthcare USA, Inc.: New York; 2007; pp 125-155.

46. Harris, D.C. Quantitative Chemical Analysis, 4th ed., W.H. Freeman and Company: New York; 1982; p 84.

47. Dessalegne, M. Assessment of Daily Fluoride Intake of Adult Person Living in Selected Households of Dugda Woreda, Ethiopia, M.Sc. Thesis, Department of Environmental Science, Addis Ababa University, Ethiopia, 2011.

48. Miller, J.N.; Miller, J.C. Statistics and Chemometrics for Analytical Chemistry, 5th ed., Pearson Practice Hall: England; 2005, pp 55-72.

49. Malinowska, E.; Inkielewicz, I.; Czarnowski, W.; Szefer, P. Food Chem. Toxicol. 2008, 46, 1055. 